\title{
Pseudomalachit z lokality Zadné Breziny pri Gemerskej Polome (Slovenská republika)
}

\author{
Pseudomalachite from the Zadné Breziny occurrence near Gemerská Poloma \\ (Slovak Republic)
}

\author{
Martin ŠteVko ${ }^{1,2) *}$, JIŘí SeJKORA ${ }^{2)}$ a ZdenĚK DolniČEK ${ }^{2)}$ \\ 1)Ústav vied o Zemi, Slovenská akadémia vied, Dúbravská cesta 9, 84005 Bratislava, Slovenská republika; \\ *e-mail: msminerals@gmail.com \\ 2)Mineralogicko-petrologické oddělení, Národní muzeum, Cirkusová 1740, 19300 Praha 9 - Horní Počernice,
} Česká republika

Števko M, Sejkora J, Dolní̌̌ek Z (2020) Pseudomalachit z lokality Zadné Breziny pri Gemerskej Polome (Slovenská republika). Bull Mineral Petrolog 28(2): 290-294 ISSN: 2570-7337

\begin{abstract}
A new occurrence of pseudomalachite was recently discovered at the Zadné Breziny copper occurrence near Gemerská Poloma, Rožňava Co., Košice Region, Slovakia. It forms dark green rich coatings and crusts, which consist of individual hemispherical aggregates up to $7 \mathrm{~mm}$ in size. Pseudostalactites up to $6 \mathrm{~mm}$ in size were also rarely observed. Pseudomalachite occurs in fractures and cavities of the quartz gangue or in fractures of the wall rock. It is associated with malachite, cuprite and native copper. The refined unit-cell parameters (for the monoclinic space group $\left.P 2_{1} / c\right)$ are a 4.4805(5) $\AA, b 5.7504(6) \AA, c$ 17.045(2) $\AA, \beta$ 91.12(1) $)^{\circ}$ and $V$ 439.06(6) $\AA^{3}$. Except of dominant contents of $\mathrm{Cu}$ and $\mathrm{P}$ only minor amounts of Al (up to $0.04 \mathrm{apfu}$ ), Fe (up to $0.02 \mathrm{apfu}$ ), As (up to $0.07 \mathrm{apfu}$ ) and S (up to $0.01 \mathrm{apfu}$ ) were detected in studied samples of pseudomalachite from the Zadné Breziny occurrence.
\end{abstract}

Key words: pseudomalachite, X-ray powder data, chemical composition, supergene minerals, Zadné Breziny, Gemerská Poloma, Slovak Republic

Obdrženo 8. 9. 2020; prijiato 7. 11. 2020

\section{Úvod}

Pseudomalachit, $\mathrm{Cu}_{5}\left(\mathrm{PO}_{4}\right)_{2}(\mathrm{OH})_{4}$ patrí k relatívne častým supergénnym minerálom predovšetkým $v$ oxidačných zónach ložísk medi. Jeho najvýznamnejšou lokalitou na území Slovenskej republiky je Cu ložisko Podlipa pri L'ubietovej, kde patrí k najčastejším supergénnym fázam a vytvára kôry a bohaté polgul'ovité agregáty, často $v$ asociácii spolu $\mathrm{s}$ malachitom a libethenitom (Zipser 1817; Zepharovich 1859; Figuschová 1977; Števko et al. 2017). Hyršl (1991) na tejto lokalite potvrdil aj prítomnost' d'alších dvoch polymorfných modifikácií $\mathrm{Cu}_{5}\left(\mathrm{PO}_{4}\right)_{2}(\mathrm{OH})_{4}$ : reichenbachitu a ludjibaitu. Zipser (1817) tiež uvádza výskyt pseudomalachitu (Phosphor-Kupfer) z bane Šramky pri Betliari (dnes v katastri obce Gemerská Poloma). Novšie bol pseudomalachit zistený aj na lokalite Breziny pri Henclovej (Števko et al. 2008) a na ložisku Piesky pri Španej Doline, kde bol zistený takmer kompletný tuhý roztok medzi pseudomalachitom a cornwallitom (Števko, Sejkora 2012, 2014).

Tento krátky príspevok prináša informácie o novom výskyte pseudomalachitu z oxidačnej zóny hydrotermálnej mineralizácie na lokalite Zadné Breziny pri Gemerskej Polome a jeho detailnú mineralogickú charakteristiku.

\section{Geologicko-ložisková charakteristika lokality}

Výskyt hydrotermálnej žilnej mineralizácie Zadné Breziny (označovaný tiež ako Zadná Brezina alebo žila Dlhá dolina) sa nachádza približne $7.5 \mathrm{~km}$ na SSV od obce Gemerská Poloma, asi 1.3 km na V od osady Podsúl'ová, na severnom svahu Dlhej doliny. GPS koordináty najvyš-

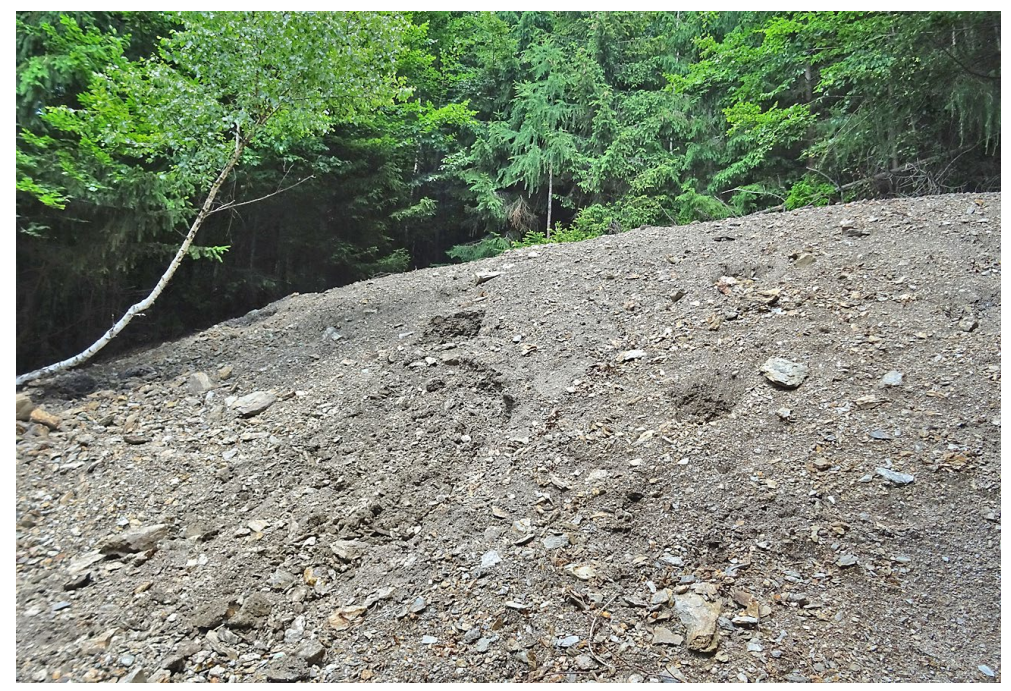

Obr. 1 Najvyššia halda na lokalite Gemerská Poloma-Zadné Breziny, foto M. Števko, júl 2020. 
šej haldy sú: $48.776568^{\circ} \mathrm{N}$ a $20.497856^{\circ} \mathrm{E}$ $820 \mathrm{~m} \mathrm{n}$. $\mathrm{m}$.

Hydrotermálna kremeňovo-karbonátová žila so sulfidmi je vyvinutá v sericitických fylitoch a lyditoch vlachovského súvrstvia (sensu Bajaník et al. 1984) respektíve smolníckeho súvrstvia (sensu Grecula et al. 2009) gelnickej skupiny gemerika. Smer žily je podl'a starých banských prác SV - JZ, mocnost' maximálne do $0.5 \mathrm{~m}$ a jej smerná dížka dosahuje cca $500 \mathrm{~m}$. Bohatšie zrudnenie je prítomné len v centrálnej časti a žilná výplň je predstavovaná kremeňom, dolomitom, kalcitom, chloritom, chalkopyritom, pyritom a arzenopyritom. Západným pokračovaním tejto žily môže byt' žila Podsúl'ová (Václav 1966; Grecula et al. 1995). Podl'a zachovaných archívnych údajov a máp bola žila predmetom prieskumu a malej t'ažby najmä v prvej polovici 19. storočia. $\mathrm{Na}$ mapách banských prác medenej bane Zadná Brezina z roku 1838 a 1842 sa uvádza štôlňa Vyšný Stephani a niekol'ko d'alších štôlní, pričom je evidentné, že banské práce mali prevažne sledný charakter (Lazár 1959). Súčasná situácia banských prác $v$ teréne dobre zodpovedá údajom uvedeným na zachovaných banských mapách.

Vzorky žiloviny so sekundárnymi minerálmi boli zbierané najmä na najvyššej halde (obr. 1) a na malej halde, ktorá sa nachádza tesne pod ňou. Na haldách $v$ nižšej časti lokality dominuje žilovina s primárnou mineralizáciou (pyrit, chalkopyrit) a sekundárne minerály sú zriedkavejšie.

\section{Metodika}

Röntgenové práškové difrakčné údaje pseudomalachitu boli získané pomocou práškového difraktometra Bruker D8 Advance (Národní muzeum, Praha, ČR) s polovodičovým pozične citlivým detektorom LynxEye s využitím CuKa žiarenia za nasledovných podmienok: napätie $40 \mathrm{kV}$, prúd 40 $\mathrm{mA}$, krok $0.01^{\circ} 2 \theta$, čas $8 \mathrm{~s} / \mathrm{krok}$ detektoru, celkový čas experimentu cca 15 hodín. Pripravený práškový preparát bol pre zníženie pozadia záznamu nanesený bez média na nosič zhotovený z monokryštálu Si. Pozície jednotlivých difrakčných maxím boli vyhodnotené pomocou programu ZDS pre DOS (Ondruš 1993) za použitia profilovej funkcie Pearson VII a indexované na základe teoretického záznamu, ktorý bol vypočítaný programom Lazy Pulverix (Yvon et al. 1977) z publikovaných údajov o kryštálovej štruktúre pseudomalachitu. Mriežkové parametre boli spresnené pomocou programu Burnhama (1962).

Chemické zloženie pseudomalachitu bolo kvantitatívne študované pomocou elektrónového mikroanalyzátora Cameca SX100 (Národní muzeum, Praha, ČR; analytik Z. Dolníček) za týchto podmienok: WD analýza, napätie $15 \mathrm{kV}$, prúd $10 \mathrm{nA}$, priemer

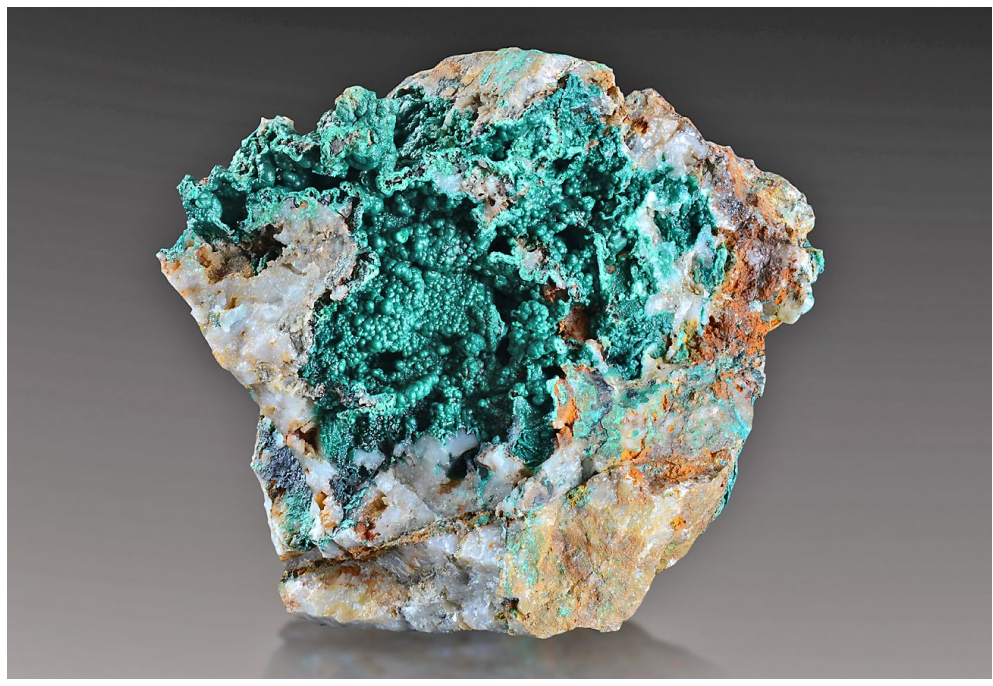

Obr. 2 Bohaté kôry pseudomalachitu zložené z polgul'ovitých agregátov $v$ dutinách kremeňovej žiloviny, rozmery vzorky sú $7 \times 6 \mathrm{~cm}$, foto A. Russ.

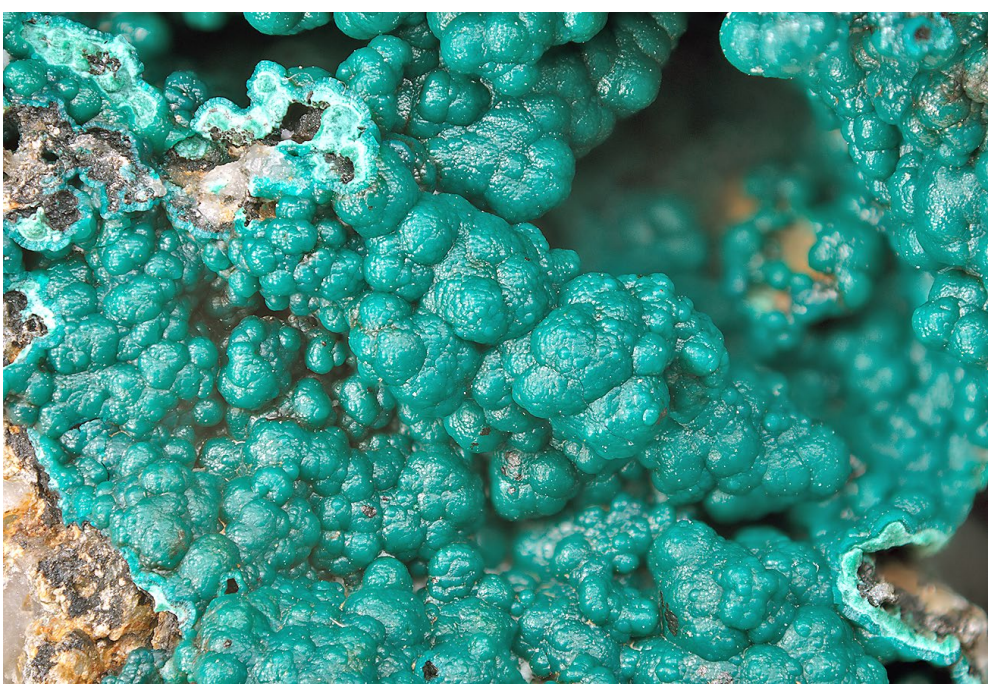

Obr. 3 Detail na polgul'ovité agregáty pseudomalachitu, šírka záberu je $16 \mathrm{~mm}$, foto $P$. Škácha.

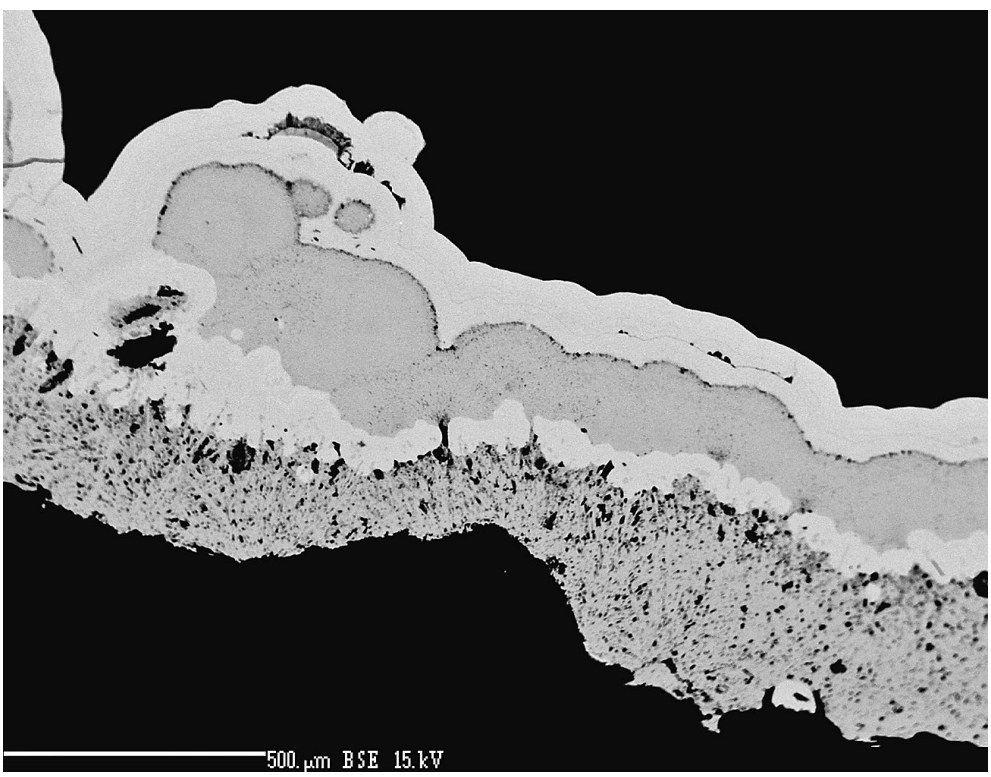

Obr. 4 Striedanie vrstiev malachitu (sivý) a pseudomalachitu (biely) $\checkmark$ priečnom reze agregátov, BSE foto Z. Dolníček. 
Tabul'ka 1 Röntgenové práškové údaje pseudomalachitu z Gemerskej Polomy

\begin{tabular}{|c|c|c|c|c|c|c|c|c|c|c|c|c|c|c|c|c|c|}
\hline$I_{o b s .}$ & $d_{o b s .}$ & $d_{\text {calc. }}$ & $h$ & $k$ & I & $I_{o b s .}$ & $d_{o b s .}$ & $d_{\text {calc. }}$ & $h$ & $k$ & I & $I_{o b s .}$ & $d_{o b s .}$ & $d_{\text {calc. }}$ & $h$ & $k$ & \\
\hline 0.1 & 8.503 & 8.521 & 0 & 0 & 2 & 3.2 & 2.3332 & 2.3341 & 1 & 2 & -2 & 0.4 & 1.7076 & 1.7072 & 1 & 2 & 7 \\
\hline 2.0 & 4.762 & 4.767 & 0 & 1 & 2 & 4.0 & 2.3203 & 2.3212 & 1 & 2 & 2 & 0.7 & 1.6945 & 1.6946 & 2 & 2 & -3 \\
\hline 100.0 & 4.476 & 4.480 & 1 & 0 & 0 & 10.8 & 2.2395 & 2.2418 & 0 & 1 & 7 & 0.4 & 1.6799 & 1.6798 & 1 & 1 & -9 \\
\hline 0.5 & 4.257 & 4.260 & 0 & 0 & 4 & & & 2.2398 & 2 & 0 & 0 & 0.6 & 1.6706 & 1.6707 & 0 & 3 & 5 \\
\hline 11.8 & 3.468 & 3.471 & 1 & 1 & -1 & 0.6 & 2.2167 & 2.2177 & 1 & 2 & 3 & 0.8 & 1.6234 & 1.6233 & & 2 & 4 \\
\hline 4.5 & 3.447 & 3.450 & 1 & 1 & 1 & 0.7 & 2.1974 & 2.1977 & 0 & 2 & 5 & 0.9 & 1.5996 & 1.5990 & 2 & 1 & -7 \\
\hline 1.4 & 3.280 & 3.282 & 1 & 1 & -2 & 0.5 & 2.1313 & 2.1302 & 0 & 0 & 8 & 0.4 & 1.5790 & 1.5787 & & 2 & -5 \\
\hline 6.7 & 3.118 & 3.118 & 1 & 0 & -4 & 3.1 & 2.0937 & 2.0945 & 1 & 2 & 4 & 0.5 & 1.5707 & 1.5704 & 2 & 1 & 7 \\
\hline 5.9 & 3.057 & 3.057 & 1 & 0 & 4 & 1.0 & 2.0186 & 2.0194 & 1 & 1 & -7 & 0.6 & 1.5603 & 1.5605 & 1 & 3 & \\
\hline 1.4 & 3.020 & 3.022 & 1 & 1 & -3 & 0.9 & 1.9989 & 1.9987 & 2 & 0 & -4 & 1.5 & 1.5590 & 1.5589 & & & \\
\hline 7.2 & 2.979 & 2.980 & 1 & 1 & 3 & 0.6 & 1.9630 & 1.9633 & 1 & 2 & 5 & 1.0 & 1.5293 & 1.5287 & 2 & 0 & 8 \\
\hline 1.9 & 2.932 & 2.932 & 0 & 1 & 5 & 1.5 & 1.9474 & 1.9476 & 2 & 1 & 3 & 0.3 & 1.5064 & 1.5060 & 0 & 3 & 7 \\
\hline 1.4 & 2.873 & 2.875 & 0 & 2 & c & 0.6 & 1.8584 & 1.8579 & 0 & 2 & 7 & 1.6 & 1.4933 & 1.4932 & & 0 & \\
\hline 0.6 & 2.837 & 2.840 & 0 & 0 & 6 & 0.7 & 1.8175 & 1.8162 & 0 & 3 & 3 & 0.4 & 1.4664 & 1.4660 & 0 & 2 & 10 \\
\hline 0.4 & 2.832 & 2.835 & 0 & 2 & 1 & 0.4 & 1.7960 & 1.7945 & 2 & 1 & -5 & 0.3 & 1.4384 & 1.4386 & & 3 & -2 \\
\hline 2.5 & 2.723 & 2.724 & 0 & 2 & 2 & 2.2 & 1.7660 & 1.7670 & 2 & 2 & 0 & 0.8 & 1.4327 & 1.4325 & 0 & 4 & \\
\hline 0.6 & 2.698 & 2.700 & 1 & 1 & 4 & & & 1.7656 & 2 & 1 & 5 & & & 1.4328 & 1 & 3 & -7 \\
\hline 0.6 & 2.565 & 2.565 & 0 & 2 & 3 & 0.5 & 1.7551 & 1.7548 & 2 & 2 & 1 & 2.6 & 1.4181 & 1.4176 & c & 4 & \\
\hline 1.8 & 2.4729 & 2.4724 & 1 & 1 & -5 & 0.6 & 1.7426 & 1.7422 & 2 & 0 & 6 & 1.4 & 1.3943 & 1.3937 & 0 & 4 & s \\
\hline 5.5 & 2.4344 & 2.4345 & 1 & 1 & 5 & 3.6 & 1.7354 & 1.7355 & 2 & 2 & -2 & & & 1.3944 & 3 & 1 & \\
\hline 3.6 & 2.4194 & 2.4202 & 1 & 0 & -6 & 1.4 & 1.7248 & 1.7253 & 1 & 2 & -7 & & & & & & \\
\hline 10.9 & 2.3910 & 2.3922 & 1 & 2 & 1 & & 1.7248 & 1.7249 & 2 & 2 & 2 & & & & & & \\
\hline
\end{tabular}

Tabul'ka 2 Mriežkové parametre pseudomalachitu z Gemerskej Polomy (indexované v monoklinickej priestorovej grupe $P 2, / c)$ a ich porovnanie s publikovanými údajmi

\begin{tabular}{llllll}
\hline & $a[\AA]$ & $b[\AA]$ & $c[\AA]$ & $\beta\left[{ }^{0}\right]$ & $V\left[\AA^{3}\right]$ \\
\hline táto práca & $4.4805(5)$ & $5.7504(6)$ & $17.045(2)$ & $91.12(1)$ & $439.06(6)$ \\
Toman et al. (2016) & $4.4781(2)$ & $5.7590(2)$ & $17.0278(8)$ & $90.894(4)$ & $439.09(2)$ \\
Števko et al. (2008) & $4.4799(5)$ & $5.7485(7)$ & $17.061(2)$ & $91.13(1)$ & $439.27(6)$ \\
Malý, Sejkora (2004) & $4.484(1)$ & $5.755(1)$ & $17.049(5)$ & $91.11(2)$ & $439.8(1)$ \\
Shoemaker et al. (1977) & $4.4728(4)$ & $5.7469(5)$ & $17.032(3)$ & $91.043(7)$ & 437.7 \\
Ghose (1963) & 4.47 & 5.75 & 17.08 & 91.12 & 438.9 \\
Hutton (1959) & $4.471(5)$ & $5.747(7)$ & $17.02(2)$ & $91.01(8)$ & $437.3(6)$ \\
Berry (1950) & $4.47(1)$ & $5.75(1)$ & $17.01(5)$ & $90.9(2)$ & $436 .(1)$ \\
\hline
\end{tabular}

Tabul'ka 3 Reprezentatívne chemické analýzy pseudomalachitu z Gemerskej Polomy (hm. \%)

\begin{tabular}{|c|c|c|c|c|c|c|c|c|c|c|c|c|c|c|c|}
\hline & P1 & P1 & P1 & P1 & P1 & P1 & P2 & P2 & P2 & P2 & P3 & P3 & P3 & P3 & P3 \\
\hline uO & .54 & 4.59 & 64.41 & .53 & 4.95 & 65.07 & 63.77 & 64.16 & 65.41 & 65.24 & 65.35 & 65.42 & 66.05 & 65.06 & 66.29 \\
\hline $\mathrm{e}_{2} \mathrm{O}_{3}$ & .16 & 0.00 & 0.00 & 0.23 & 0.00 & 0.00 & 0.00 & 0.00 & 0.00 & 0.00 & 0.00 & 0.00 & 0.17 & 0.00 & 0.00 \\
\hline${ }_{2} \mathrm{O}_{3}$ & 0.00 & 0.00 & 0.00 & 0.00 & 0.00 & 0.00 & 0.00 & 0.00 & 0.00 & 0.00 & 0.31 & 0.12 & 0.00 & 0.00 & 0.00 \\
\hline $\mathrm{S}_{2} \mathrm{O}_{5}$ & 0.27 & 0.24 & 0.20 & 0.31 & 0.00 & 0.00 & 1.32 & 0.80 & 0.68 & 1.02 & 0.21 & 0.27 & 0.00 & 0.00 & 0.38 \\
\hline 0 & 3.38 & 22.93 & 22.68 & 23.14 & 23.10 & 23.15 & 22.04 & 21.89 & 22.30 & 22.81 & 23.26 & 22.93 & 23.05 & 23.10 & 22.82 \\
\hline $\mathrm{H}_{2} \mathrm{O}^{*}$ & 16 & 5.83 & 5.89 & .79 & 5.91 & 5.90 & 5.74 & 6.01 & 6.16 & 5.85 & 6.06 & 6.09 & 6.24 & 5.94 & 6.24 \\
\hline tal & .51 & 93.63 & 93.23 & 94.09 & 3.96 & 94.22 & 92.87 & 92.86 & 94.55 & 94.92 & 95.19 & 94.83 & 95.51 & 94.10 & 95.73 \\
\hline $\mathrm{u}^{2+}$ & & 987 & 031 & 919 & 017 & 997 & & 115 & 37 & 967 & 86 & 054 & 113 & .026 & .131 \\
\hline & 12 & .000 & 0.000 & 017 & .000 & 0.000 & 0.000 & .000 & 0.000 & 0.000 & 0.000 & 0.000 & .013 & 0.000 & 0.000 \\
\hline $3+$ & 000 & 0.000 & 0.000 & 0.000 & 0.000 & 0.000 & 0.000 & 0.000 & 0.000 & 0.000 & 0.037 & 0.014 & 0.000 & 0.000 & 0.000 \\
\hline & 055 & 4.987 & 5.031 & 4.936 & 5.017 & 4.997 & 4.979 & 5.115 & 5.137 & 4.967 & 5.023 & 5.069 & 5.126 & 5.026 & 5.131 \\
\hline $\mathrm{s}^{5+}$ & 014 & 0.013 & 0.011 & 0.016 & 0.000 & 0.000 & 0.071 & 0.044 & 0.037 & 0.054 & 0.011 & 0.014 & 0.000 & 0.000 & 0.020 \\
\hline & 986 & 984 & 1.985 & 977 & .000 & 1.992 & 929 & 1.956 & 1.963 & 1.946 & 989 & 1.986 & 2.000 & 2.000 & 1.980 \\
\hline $6+$ & 000 & 0.003 & 0.004 & 0.007 & 0.000 & 0.008 & 0.000 & 0.000 & 0.000 & 0.000 & 0.000 & 0.000 & 0.000 & 0.000 & 0.000 \\
\hline & 2.000 & 2.000 & 2.000 & 2.000 & 2.000 & 2.000 & 2.000 & 2.000 & 2.000 & 2.000 & 2.000 & 2.000 & 2.000 & 2.000 & 2.000 \\
\hline כH & 4.121 & 3.976 & 4.065 & 3.896 & 4.035 & 4.001 & 3.958 & 4.230 & 4.275 & 3.933 & 4.082 & 4.152 & 4.266 & 4.052 & 426 \\
\hline
\end{tabular}


elektrónového lúča $5 \mu \mathrm{m}$, štandardy a použité spektrálne čiary: albit (NaKa), barit (BaL $\alpha)$, celestín (SKa, SrL $\beta)$, diopsid (MgKa), fluórapatit (CaKa, PKa), halit (CIKa), hematit (FeKa), chalkopyrit (CuKa), klinoklas (AsLa), LiF $(F K \alpha)$, rodonit (MnKa), sanidín (AlKa, SiKa, KKa), vanadinit $(\mathrm{VK \alpha})$, wulfenit $(\mathrm{PbM \alpha})$ a $\mathrm{ZnO}(\mathrm{ZnKa})$. Obsahy vyššie uvedených prvkov, ktoré nie sú zahrnuté v tabul'ke, boli kvantitatívne analyzované, ale zistené koncentrácie boli pod detekčným limitom elektrónovej mikroanalýzy (cca $0.03-0.30 \mathrm{hm}$. \% pre jednotlivé prvky). Získané údaje boli korigované pomocou softvéru PAP (Pouchou, Pichoir 1985).

\section{Výsledky}

Sekundárne minerály $\mathrm{Cu}$ (malachit, pseudomalachit, kuprit, med') boli zistené $v$ dutinách a puklinách kremeňovej žiloviny ako aj na puklinách okolitých hornín. Najčastejší je malachit, ktorý vytvára svetlozelené až sýtozelené kôry, polgul'ovité agregáty alebo až $3 \mathrm{~cm}$ vel'ké radiálne agregáty. Kuprit je zriedkavejší a tvorí sýtočervené jemnozrnné agregáty do $1 \mathrm{~cm}$, ktoré sú často intenzívne zatláčané malachitom. Med' sa vyskytuje $v$ podobe nepravidelných mikroskopických agregátov zarastených $v$ centrálnej časti agregátov kupritu.

Pseudomalachit je na lokalite Zadné Breziny relatívne častý minerál. $\mathrm{V}$ puklinách a dutinách kremeňovej žiloviny a okolitých hornín vytvára bohaté tmavozelené povlaky a kôry (obr. 2) s matným až skleným leskom, ktoré sú zložené z jednotlivých polgul'ovitých agregátov do $7 \mathrm{~mm}$ (obr. 3). Vzácne sa v dutinách žiloviny vyskytli aj pseudostalaktity do $6 \mathrm{~mm}$. Kôry a agregáty pseudomalachitu bežne pokrývajú plochy aj viac ako $100 \mathrm{~cm}^{2}$ a vel'mi často narastajú na kôrach a agregátoch malachitu. $\checkmark$ niekol'kých prípadoch bolo $v$ priereze agregátov pozorované koncentrické striedanie vrstiev pseudomalachitu a malachitu (obr. 4), čo naznačuje lokálne ale výrazné zmeny $v$ aktivite $\mathrm{PO}_{4} / \mathrm{CO}_{3}$ počas formovania supergénnej zóny na tejto lokalite.

Röntgenové práškové difrakčné údaje pseudomalachitu z lokality Gemerská Poloma - Zadné Breziny (tab. 1) dobre zodpovedajú publikovaným údajom pre túto minerálnu fázu ako aj teoretickému práškovému záznamu, ktorý bol vypočítaný z údajov o kryštálovej štruktúre pseudomalachitu publikovanej v práci Shoemaker et al. (1977). Nevýrazné rozdiely $v$ intenzite jednotlivých difrakčných maxím sú spôsobené prednostnou orientáciou študovaného práškového preparátu. Prítomnost' iných polymorfných modifikácií $\mathrm{Cu}_{5}\left(\mathrm{PO}_{4}\right)_{2}(\mathrm{OH})_{4}$ : ludjibaitu (Piret, Deliens 1988; Shoemaker et al. 1981) a reichenbachitu (Sieber et al. 1987) nebola v študovaných vzorkách (celkovo bolo študovaných 5 rozdielnych vzoriek) potvrdená ani $v$ minoritnom množstve. Spresnené mriežkové parametre pseudomalachitu z Gemerskej Polomy sú v tabul'ke 2 porovnané s publikovanými údajmi pre túto minerálnu fázu.

Reprezentatívne mikroanalýzy troch vzoriek pseudomalachitu z Gemerskej Polomy (P1, P2, P3) sú uvedené v tabul'ke 3. V katiónovej pozícii boli lokálne zistené len minoritné obsahy $\mathrm{Al}$ (do 0.04 apfu) a Fe (do 0.02 apfu). $\checkmark$ aniónovej pozícii študovaných vzoriek pseudomalachitu z Gemerskej Polomy sú okrem dominantného obsahu $\mathrm{P}$ pravidelne zastúpené aj minoritné množstvá As (do $0.07 \mathrm{apfu}$ ) a len lokálne aj S (do $0.01 \mathrm{apfu}$ ).

\section{Záver}

Na lokalite Zadné Breziny pri Gemerskej Polome bol zistený nový výskyt pseudomalachitu $v$ asociácii spolu s malachitom, kupritom a med'ou. Uvedená asociácia sekundárnych minerálov vznikla zvetrávaním primárnych rudných minerálov (najmä chalkopyritu) v prostredí supergénnej zóny in-situ, pričom vzhl'adom na výskyt koncentrických agregátov malachitu a pseudomalachitu je pravdepodobné, že počas vývoja supergénnej zóny lokálne dochádzalo $\mathrm{k}$ výrazným zmenám $\mathrm{v}$ aktivite $\mathrm{PO}_{4} /$ $\mathrm{CO}_{3}$. Zdrojom fosforu bolo najpravdepodobnejšie okolité horninové prostredie.

\section{Pod'akovanie}

Milou povinnost'ou autorov je pod'akovat' Mgr. Albertovi Russovi a Mgr. Pavlovi Škáchovi Ph.D. za fotografie pseudomalachitu. Predložená práca vznikla vd’aka finančnej podpore Ministerstva kultury ČR $v$ rámci inštitucionálneho financovania dlhodobého koncepčného rozvoja výskumnej organizácie Národní muzeum (DKRVO 20192023/1.II.b, 00023272).

\section{Literatúra}

Bajaník Š, Ivanička J, Mello J, Pristaš J, Reichwalder P, SNOPKo L, VozÁr J, VozÁrová A (1984) Geologická mapa Slovenského rudohoria, východná čast' 1:50 000. ŠGÚDŠ, Bratislava

BerRY LG (1950) On pseudomalachite and cornetite. Am Mineral 35: 365-385

BuRNHAM CHW (1962) Lattice constant refinement. Carnegie Inst Washington Year Book 61: 132-135

FIGUSCHOVÁ M (1977) Sekundárne minerály medi z L'ubietovej. In: Zborník referátov z konferencie Ložiskotvorné procesy Západných Karpát, Bratislava, 135-137

GHOSE S (1963) The crystal structure of pseudomalachite, $\mathrm{Cu}_{5}\left(\mathrm{PO}_{4}\right)_{2}(\mathrm{OH})_{4}$. Acta Cryst 16: 124-128

Grecula P, Abony A, Abonyiová M, Antaš J, Bartalský B, BARTALSKÝ J, DianIŠKa I, ĎUĎa R, Gargulák M, GaZdAČKo L', HudÁČEK J, KobulskÝ J, LÖRINCZ L, MACKo J, NÁVESŇ́́K D, NÉmeth Z, Novotný L, Radvanec M, RojkoVIČ I, RoZložNí L, VARČEK C, ZLocha Z (1995) Ložiská nerastných surovín Slovenského rudohoria. Zväzok 1. Geocomplex, Bratislava, 1-834

Grecula P, Kobulský J, GazdačKo L', Németh Z, HrašKo L', Novotný L, Maglay J (2009) Geologická mapa Spišsko-gemerského rudohoria 1:50 000. ŠGÚDŠ, Bratislava

Hutton CO (1959) An occurrence of pseudomalachite at Safford, Arizona. Am Mineral 44: 1298-1301

HYRŠL J (1991) Three polymorphs of $\mathrm{Cu}_{5}\left(\mathrm{PO}_{4}\right)_{2}(\mathrm{OH})_{4}$ from L'ubietová, Czechoslovakia. N Jb Mineral, Mh 6: 281287

LAZÁR V (1959) Zpráva o archívno-výskumnom úkole „Ankeritový pruh Hanková-Volovec" v roku 1959, rešeršná správa. MS, archív ŠGúDŠ-Geofond, Bratislava, 82,6865

Malý KD, SEJKoRA J (2004) Supergenní Cu a Bi mineralizace na lokalitě Tři Sekery u Mariánských Lázní. Bull mineral-petrolog Odd Nár Muz (Praha) 12: 136-139

ONDRUŠ P (1993) ZDS - A computer program for analysis of X-ray powder diffraction patterns. Materials Science Forum, 133-136, 297-300, EPDIC-2. Enchede

PiRet P, Deliens M (1988) Description de la ludjibaïte, un polymorphe de la pseudomalachite, $\mathrm{Cu}_{5}\left(\mathrm{PO}_{4}\right)_{2}(\mathrm{OH})_{4}$. Bull Minéral 111: 167-171 
Pouchou JL, PICHOIR F (1985) "PAP" ( $\varphi \rho Z)$ procedure for improved quantitative microanalysis. In: Microbeam Analysis (J. T. Armstrong, ed.). San Francisco Press, San Francisco, 104-106

Shoemaker GL, Anderson JB, Kostiner E (1977) Refinement of the crystal structure of pseudomalachite. Am Mineral 62: 1042-1048

Shoemaker GL, Anderson JB, Kostiner E (1981) The crystal structure of a third polymorph of $\mathrm{Cu}_{5}\left(\mathrm{PO}_{4}\right)_{2}(\mathrm{OH})_{4}$. Am Mineral 66: 169-175

Sieber NHW, Tillmanns E, Medenbach O (1987) Hentschelite, $\mathrm{CuFe}_{2}\left(\mathrm{PO}_{4}\right)_{2}(\mathrm{OH})_{2}$, a new member of the lazulite group, and reichenbachite, $\mathrm{Cu}_{5}\left(\mathrm{PO}_{4}\right)_{2}(\mathrm{OH})_{4}$, a polymorph of pseudomalachite, two new copper phosphate minerals from Reichenbach, Germany. Am Mineral 72: 404-408

ŠTEVKo M, SEJKORA J (2012) Supergene arsenates of copper from Špania Dolina-Piesky deposit, Central Slovakia. Acta Mineral-Petrogr, Abstr Ser 7: 130

Števko M, SeJkora J (2014) Contribution to chemical composition of chalcophyllite, pseudomalachite and olivenite group minerals from Špania Dolina-Piesky, Slovak Republic. In: Book of abstracts, CEMC 2014, 133-134
Števko M, Sejkora J, Ozdín D (2008) Henclová - nová lokalita pseudomalachitu v Slovenskej republike. Bull mineral-petrolog Odd Nár Muz (Praha) 16: 36-39

Števko M, SeJkora J, Súlovec Š (2017) Príspevok k chemickému zloženiu libethenitu z typovej lokality: ložisko Podlipa, L'ubietová (Slovenská republika). Bull Mineral Petrolog 25(2): 252-259

Toman J, Hrazdil V, Sejkora J (2016) Pseudomalachit a descloizit $v$ supergenní minerální asociaci z lokality Krucemburk (Česká republika). Acta Mus Moraviae Sci geol 101(1-2): 33-43

VÁCLAV J (1966) Mineralogicko-paragenetické a geochemické pomery hydrotermálnych rudných žíl v oblasti Švedlár-Stará Voda-Volovec. Dielčia záverečná správa za roky 1962-1965. MS, archív ŠGúDŠ-Geofond, Bratislava, 1-199, 17537

Yvon K, Jeitschko W, Parthé E (1977) Lazy Pulverix, a computer program for calculation $\mathrm{X}$-ray and neutron diffraction powder patterns. J Appl Cryst 10: 73-74

ZePHAROVICH V (1859) Mineralogisches Lexicon für das Kaiserthum Österreich. Band I. 1-627, Wilhelm Braumüller, Wien

ZIPSER CHA (1817) Versuch eines topograhisch-mineralogischen Handbuches von Ungern. 1-440, Carl Friedrich Wigand, Oedenburg 